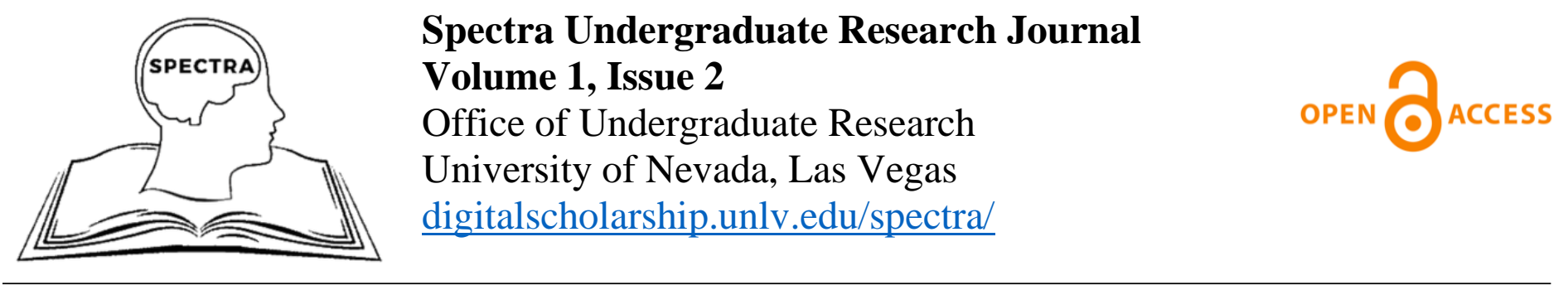

\begin{tabular}{|c|}
\hline Category \\
\hline Arts, Humanities, and Social Sciences $>$ Social Sciences $>$ Criminal Justice \\
\hline Received \\
\hline March 2, 2021 \\
\hline Accepted \\
\hline July 19,2021 \\
\hline Published \\
\hline August 13, 2021 \\
\hline Article Title \\
\hline Racial Profiling: Understanding the Practice of Stop-and-Frisk in New York City \\
\hline Authors \\
\hline Lisa Ly $(\mathrm{LL})^{1 *}$ \\
\hline Author Affiliations \\
\hline${ }^{1}$ Department of Criminal Justice, University of Nevada, Las Vegas, Las Vegas, NV, USA. \\
\hline Corresponding Author \\
\hline $\begin{array}{l}\text { *Lisa Ly, 1y12@unlv.nevada.edu } \\
\text { iD https://orcid.org/0000-0002-3687-9665 }\end{array}$ \\
\hline Author Contributions \\
\hline $\begin{array}{l}\text { LL: Contributed conceptualization, data collection, drafting of paper, formal analysis, methodology, } \\
\text { and editing of manuscript }\end{array}$ \\
\hline Copyright \\
\hline $\begin{array}{l}\text { (c) Articles in Spectra are freely available under a Creative Commons Attribution } \\
\text { License (CC BY 4.0) which allows others to re-use the work without permission as } \\
\text { long as the work is properly cited. }\end{array}$ \\
\hline ISSN \\
\hline $2766-7227$ \\
\hline Data Availability Statement \\
\hline The author confirms that all data underlying the findings are fully available without restriction. \\
\hline Conflicts of Interest \\
\hline The author declares that no conflicts of interest exist. \\
\hline Ethical Considerations \\
\hline $\begin{array}{l}\text { Given that this project did not involve human or animal subjects, no IRB or IACUC approval was } \\
\text { needed. No data presented in this paper are derived from participants and all program elements are } \\
\text { publicly shared. }\end{array}$ \\
\hline Funding \\
\hline No funding was used to conduct this research. \\
\hline Recommended Citation \\
\hline $\begin{array}{l}\text { Ly, L. (2021). Racial profiling: Understanding the practice of stop-and-frisk in New York City. } \\
\text { Spectra Undergraduate Research Journal, } 1(2), 1-23 \text {. https://doi.org/10.9741/2766-7227.1006 }\end{array}$ \\
\hline
\end{tabular}




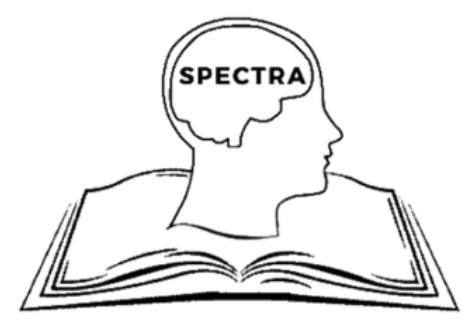

Spectra Undergraduate Research Journal

Volume 1, Issue 2

Office of Undergraduate Research

University of Nevada, Las Vegas

digitalscholarship.unlv.edu/spectra/

\title{
Racial Profiling: Understanding the Practice of Stop-and-Frisk in New York City
}

Lisa Ly ${ }^{1}$

\section{Author Affiliations:}

${ }^{1}$ Department of Criminal Justice, University of Nevada, Las Vegas, Las Vegas, NV, USA.

\begin{abstract}
Racial profiling has become a prominent issue in modern policing today. Instead of being based on individual suspicion, racial profiling embodies a belief that people of color are continuously singled out by the police for scrutiny and harassment. Policies and procedures make the Black community vulnerable to police discrimination and racial profiling. Floyd et al. v. City of New York et al. (2013) declared that the New York Police Department's (NYPD) practice of stop-and-frisk was racially profiling Black civilians. This study sought (1) to determine if the NYPD post-Floyd is still engaging in racial profiling towards Black civilians; and (2) to evaluate the relationship between race and the number of stops, frisks, and arrests with the T-test. Based on the data released by the NYPD from 2011 to 2015 and $2019(\mathrm{~N}=1,492,295)$, results indicated that the NYPD is engaging in racial profiling towards Black civilians post-Floyd and that there is a relationship between race and the number of stops, frisks, and arrests between Black and White civilians. The results contribute to a wider research consensus that racial profiling and discrimination are a presence in police practices in the United States.
\end{abstract}

Keywords: stop-and-frisk, racial profiling, New York City

The purpose of this study is to investigate the continuation of the practice of stop-and-frisk in New York City. After a review of research on stop-and-frisk practices within the United States (U.S.), the findings and policy suggestions will then be presented.

The police, as law enforcement, have the responsibilities to prevent crime and preserve peace. Police legitimacy is based on a citizen's perception of the police based on how they are treated (Noppe et al., 2017; Tyler \& Huo, 2002). The relationship between the police and the communities of color have been abysmal (Alexander, 2010; Stack, 2018). Individuals from communities of color tend to perceive law enforcement with negative attitudes and distrust (Sunshine \& Tyler, 2003).
In situations involving police authority and discretion, it is indicated that the police tend to treat people of color differently in comparison to their White counterparts (Brooks, 2020; Gabrielson et al., 2014; Smith et al., 2009). Studies have found that Black and Hispanic civilians are overrepresented in policies and practices, such as stop-and-frisk (Farrell et al., 2004; Holmes, 2000; New York State Office of the Attorney General, 1999; Smith \& Alpert, 2007). Among Black individuals, there is a distrust of law enforcement and their legitimacy because of discriminatory treatments, such as racial profiling (Bobo \& Thompson, 2006).

The discriminatory act of racial profiling occurs when law enforcement targets individuals based on race, ethnicity, religion, or national origin (American Civil Liberties Union, 2020). Racial 
profiling by police officers has become the subject of focus by the media following several high-profile deaths of unarmed Black civilians (Smiley, 2019). The results from several reported racial profiling studies have all indicated that Black civilians are more likely to be stopped, searched, and arrested (Hetey et al., 2016; New York State Office of the Attorney General, 1999; United States Government Accountability Office, 2000). These actions not only influence a civilian's perception of police legitimacy; they have consequently violated the Fourteenth Amendment.

Today, racial profiling remains hidden behind policing policies and procedures such as stop-andfrisk, consequently allowing many officers to easily express their bias and harass people of color, specifically Black civilians (Floyd et al. v. City of New York et al., 2013; Morrow et al., 2017; Smith \& Alpert, 2007). In recent years, several law enforcement agencies, such as New York City, Oakland, and Ferguson, have developed large scale, controversial Stop, Question, and Frisk (SQF) programs. These programs have generated high volumes of stops and frisks of individuals of color (Hetey et al., 2016; Morrow et al., 2017; Taylor, 2016). Due to these realities, the practice of stop-and-frisk is controversial and is often considered as a form of police violence against communities of color, Black communities specifically.

New York City's police department (NYPD) is the most prominent example associated with the practice of stop-and-frisk. This is likely due to its controversial policy, lengthy history, and legal issues associated with stop-and-frisk practices (McDonald \& Greenberg, 2002; Smith \& Bratton, 2001; Stack, 2018). To combat street crimes, former Mayor Rudolph Giuliani (1994 - 2001) formally introduced SQF as a crime control policy. This policy became vastly implemented under the administration of former Mayor Michael Bloomberg (2002- 2013). SQF in New York City enabled officers to racially profile civilians under the guise of suspicion (Floyd et al. v. City of New York et al., 2013).

SQF data, later released by the NYPD, revealed a racial disparity in the number of stops, particularly towards Black civilians (Belen, 2018; City of New York, 2020). Under the administration of Mayor Bloomberg, the city also saw NYPD's practice of stop- and-frisk declared as unconstitutional. In the landmark case, Floyd et al. v. City of New York et al. (2013), it was found that the NYPD had violated the Fourth Amendment and Fourteenth Amendment because of their unwritten policy of racial profiling. Following the ruling, a Joint Remedial Process was ordered to bring reforms to the police department and the city (Badger, 2014; Center for Constitutional Rights, 2019; Ward, 2014). Under the current Mayor, Bill de Blasio (2014 present), NYC began its sweeping reforms to the prior Giuliani SQF guidelines.

For this study, the NYPD SQF data from 2011 to 2015 and 2019 will be analyzed to determine if the NYPD post-Floyd et al. v. City of New York et al. is still engaging in racial profiling towards Black civilians. The relationship between a civilian's race and the number of stops, frisks, and arrests using the Ttest. Based on the findings, this study concluded that the NYPD has continued to engage in racial profiling towards Black civilians post-Floyd and that there is a relationship between race and the number of stops, frisks, and arrests. In addition to the findings, the conclusion provides a summary of the study, results, limitations, and directions for future research.

\section{Literature Review}

To investigate the continuation of the practice of stop-and-frisk in New York City, this section reviews landmark Supreme Court case, Terry v. Ohio, on the constitutionality and policy of stop-and-frisk and the implicit bias of law enforcement against Black civilians. In this review, there is a brief overview of Civil Rights events and closes with the history of the practice of stop-and-frisk in New York City, including COMPSTAT and the Street Crime Unit. Criticisms and protests eventually led to separate class-action lawsuits filed against the NYPD and the city charging them with racial profiling and unlawful stop-and-frisk. The following provides a historical timeline of the racial discrimination against the Black community and how it is still occurring today with the practice of stop-andfrisk in New York City.

Terry v. Ohio and Implicit Bias: The Fourth Amendment of the Constitution ensures an individual's right to the protection of privacy and property against the government's actions. To perform a search and seizure, the government must establish probable cause, 
which is a reasonable belief to suspect that an individual has committed or is committing a crime and provide a search warrant issued by a judge. The landmark Supreme Court case, Terry v. Ohio (1968), lowered the standard of evidence necessary to conduct a stop from probable cause to a lower degree of reasonable suspicion. Additionally, it also defined and validated the practice of stop-and-frisk. Stop-and-frisk, defined as two separate actions, must stem from the officer's reasonable suspicion that an individual is suspected of committing or has committed a crime. The initial stop, or a Terry stop, is more than a hunch, but not considered probable cause. A subsequent frisk is only justifiable if the officer believes the suspect in question possesses any weapons that pose a threat to the officer's safety. In sum, stop-and-frisk allows officers to stop and frisk individuals with little or no justification (Fagan \& Geller, 2015; Meares, 2015).

By lowering the standard of evidence, the Court disregarded the Fourth Amendment protections by allowing police officers the discretion to search anyone at any time. The broad level of discretion can lead to implicit bias within the practice of stop-and-frisk. Implicit bias refers to the stereotypes about a person, thing, or group that impacts one's attitude and action towards the subject (Richardson, 2017). An example of implicit bias is viewing the presence of Black individuals as being a dangerous and violent threat compared to their White counterparts (Kramer \& Remster, 2018; Quillian \& Pager, 2010; Stack, 2018).

Law enforcement, as agents of the law, should always remain neutral. It is not often the case, as some may have an unconscious or deeply rooted negative judgment about Black civilians. Viewing Black civilians as a threat to their safety can cause officers to exercise their discretion, which often leads to unequal use of force or abuse of power. For example, the killing of George Floyd at the hands of the Minneapolis Police Department in 2020 sparked criticisms worldwide regarding police excessive and unjustified use of force, brutality, and racism against George Floyd and unarmed Black individuals (Brooks, 2020). While the Supreme Court has acknowledged that the lower level of scrutiny would likely lead to discriminatory policing within the practice of stop-and-frisk, they have also refused to provide any remedy for implicit bias (Alexander, 2010; Stack, 2018; Thompson, 1999).
Before the ruling of Terry v. Ohio (1968), an amicus brief filed to the Supreme Court by the National Association for the Advancement of Colored People (NAACP) raised questions about the racism inherent in the practice of stop-and-frisk. Given the history of civil rights struggles in the U.S., there will be inevitable police discrimination against Black civilians and other underrepresented groups (Kurland \& Casper, 1975). The NAACP used the context of police brutality against peaceful Civil Rights protestors in the 1960s to affirm the presence of racist discrimination harbored by many officers (Kurland \& Casper, 1975; Schwartz, 1996). American history has viewed the Black community as a threat because of stereotypes placed upon them. This threat has likely contributed to the implicit bias against them.

Stop-and-frisk in New York City: A new form of policing brought the practice of stop-and-frisk in New York City to an all-time high in the late 1990s and early 2000s. Developed in 1994, COMPARE STATISTICS or COMPSTAT was created as a management tool that focuses on crime analysis, disorder data, problemsolving, and accountability structure (McDonald \& Greenberg, 2002; Smith \& Bratton, 2001). COMPSTAT was initially intended for police departments to identify and focus on crimeconcentrated neighborhoods. In short, the racial composition of these neighborhoods shaped police behavior and engagements with people of color.

The data derived from COMPSTAT is only limited to reported crimes and measures of police activity. Therefore, it cannot account for all crimes, including the dark figure of crime or unreported crimes (Brown \& Barganier, 2018). Through data collected from COMPSTAT, the NYPD began to extensively focus on high-crime neighborhoods densely populated by Black, Hispanic, and of a lower-income (Nash, 2018; Ward, 2014). COMPSTAT is a tool for racialized policing against people of color (Brown \& Barganier, 2018; Ward, 2014)

Originally introduced as a crime control policy, the practice of stop-and-frisk in New York City was morphed into an aggressive and racially biased policing tactic that is quite different from the original policy outlined in Terry. Between 1997 and 1998, the NYPD's Street Crime Unit (SCU)'s report revealed that out of the 45,000 stop-and-frisks, almost 35,000 
did not result in an arrest and were found innocent (Center for Constitutional Rights, 2012). From 1998 to 1999 approximately 175,000 field interrogation cards were completed by the NYPD, and although Black civilians only comprise $25.6 \%$ of the population, $50.6 \%$ of all persons stopped by the NYPD were Black (New York State Office of the Attorney General, 1999). Further analysis by the New York Attorney General (1999) revealed that for every arrest made by the SCU, 16 Black civilians were stopped-and-frisked. There was also a failure of officers to provide sufficient information on their Stop, Question, and Frisk Worksheet. These forms are reviewed and analyzed to determine whether or not the stop was lawful.

The 1999 report by the Attorney General sparked mass protests and criticism against the NYPD and its SQF policy. Fed up with the NYPD's unlawful and racially-charged practice of stop, question, and frisk, the Center for Constitutional Rights (CCR) filed a class-action lawsuit to challenge the department's policies and for the disbandment of the SCU in 1999 (Center for Constitutional Rights, 2012; Ward, 2014). CCR claimed that the NYPD was conducting the practice of stop-and-frisk without any reasonable suspicion required by the Fourth Amendment and Terry. Officers were also racially profiling young men of color, especially Black individuals, which is a violation of the Fourteenth Amendment (Center for Constitutional Rights, 2012; Daniels et al. v. the City of New York et al., 2001).

Daniels et al. v. the City of New York et al. (2001) resulted in a settlement between the city and the plaintiffs. The Southern District Court of New York found that the NYPD SCU had a history of racial profiling during their practice of stop-and-frisk. However, even before the settlement, the unit was disbanded in response to public backlash. The settlement agreement eventually required the NYPD to maintain a written anti-racial profiling policy and perform audits on officers who engage in stop-andfrisk (Center for Constitutional Rights, 2012; Stack, 2018). Settled in 2003, Daniels was the first of the two lawsuits against the city of New York to bring reforms to the NYPD.

Before 2006, there was no available database for SQF. Even then, the public could not access the information. The following year, the New York Civil
Liberties Union sued the NYPD, under the Freedom of Information Act, to disclose existing SQF data before and after 2006 (Belen, 2018; New York Civil Liberties Union and the NYCLU Foundation, 2013; Shames \& McCormack, 2019). In 2008, the New York County Supreme Court ordered the NYPD to release its SQF database. The now-public database revealed that the remedial measures under Daniels did not work as there was a remarkable increase in the practice of stop-andfrisk (Center for Constitutional Rights, 2020).

Under the mayorship of Michael Bloomberg (2002 - 2013), the NYPDs practice of stop-and-frisk drastically increased (Belen, 2018). Due to their involvement in the continued use of SQF, the Bloomberg administration was named in another federal class-action lawsuit in 2008. Similar to Daniels, Floyd et al. v. City of New York et al. (2013) challenged the constitutionality of the NYPD's practice of stopand-frisk in violation of the Fourth and Fourteenth Amendments. The police not only performed stops without reasonable suspicion, but they had racially profiled and implicitly targeted Black civilians. In 2013, the Southern District Court of New York found the NYPD's policies of stop-and-frisk unconstitutional under the Fourth Amendment (Center for Constitutional Rights, 2020; Meares, 2014). According to the Court, the NYPD had begun stopping people of color for crime prevention in contrast to the practice of Terry, which indicated that each stop must come from reasonable suspicion of criminal activity.

Based on the database and evidence presented, there was a racial disparity in the number of Black civilians being stopped and frisked compared to White civilians (City of New York, 2020). The NYPD also had an unwritten policy of targeting young Black and Hispanic men based on their appearance. For their act of racial profiling, the Court concluded that the NYPD had violated the Fourteenth Amendment because of their decision to deny Black and Hispanic civilians their equal protection of the law (Belen, 2018; Floyd et al. v. City of New York et al., 2013).

A Joint Remedial Process was ordered by the Court to bring forth a set of reforms to the NYPD's SQF. Communities affected by the racially discriminatory practice would have direct input in the process of reform (Center for Constitutional Rights, 2019). However, the process was briefly halted in 
October of 2013 when the City and the Bloomberg's administration filed an appeal to the U.S. Court of Appeals for the Second Circuit to overturn the 2013 Floyd rulings (Center for Constitutional Rights, 2019; Stack 2018). Under the newly elected Mayor Bill de Blasio, the City withdrew its appeal and announced its plan to move forward with the Joint Remedial Process in 2014 (Badger, 2014; Center for Constitutional Rights, 2019; Ward, 2014).

From 2014 to 2018, 14 recommendations for immediate reforms were outlined and given to the NYPD. Recommendations such as active body cameras, documentation of Level 1 and 2 stops, and permanent structures for officer feedback have since been put into effect (Belen, 2018; Center for Constitutional Rights, 2019). Under the current administration, the City saw a dramatic decline in its practice of SQF. However, many are still critical of the NYPD's SQF policy despite the decreasing number of reported SQF.

The ruling of Floyd and the Joint Remedial Process has resulted in a dramatic reduction of the reported SQF stops. While this reduction has been noted, racial profiling and implicit bias of law enforcement on Black civilians before and after-Floyd has not been analyzed. This study intends to examine the SQF database to determine if the NYPD is still engaging in racial profiling towards Black civilians post-Floyd and evaluate the relationship between a civilian's race and the number of stops, frisks, and arrests.

\section{Methodology}

In Floyd et al. v. City of New York et al. (2013), U.S. District Court Judge Shira A. Scheindlin, who also presided over Daniels, ruled that the NYPD's unwritten policy of targeting "the right people," meaning individuals from the communities of color, is a form of racial profiling. In her opinion, Judge Scheindlin condemned the NYPD's policy of encouraging officers to target young Black and Hispanic men based on their prevalence in local crime complaints.

The debate over racial profiling is a part of the extensive and complicated relationship between the police and Black communities. Even in the 21st century, racial discrimination and injustice remain in the criminal justice system (Alexander, 2010; Smiley, 2019). In a melting pot of cultures, New York City was and still is affected by police misconduct, especially those against the Black communities. As previous mentioned, the Bloomberg administration was under immense scrutiny for the expansion of the SQF policy, which increased by seven-fold.

Stop-and-frisk was a key issue in the 2013 mayoral race. Then-candidate Bill de Blasio ran on the promise of reforms within the NYPD, stop-and-frisk reform, and creating a legislative bill to combat racial profiling (de Blasio, 2013). The primary goal of the study was to follow up with the promises of reforms from the current Mayor Bill de Blasio. The following research questions seek to determine if Mayor de Blasio and the Joint Remedial Process has brought the necessary and badly needed reforms to New York City and the NYPD.

1. Is the New York Police Department post-Floyd et al. v. City of New York et al. still engaging in racial profiling towards Black civilians via the practice of stop-and-frisk?

2. What is the relationship between a civilian's race and the number of stops, frisks, and arrests?

a. Null Hypothesis $\left(\mathrm{H}_{\mathrm{o}}\right)$ : There is no association in the number stops, frisks, and arrests between Black and White civilians.

b. Alternative Hypothesis $\left(\mathrm{H}_{\mathrm{a}}\right)$ : There is an association in the number of stops, frisks, and arrests between Black and White civilians.

Data Sources: This study drew its variables and data from the SQF database released by the NYPD to triangulate and analyze the data to answer the research questions. This study focused on data released before, during, and after Floyd, including the latest 2019 data. A total of 1,492,295 pedestrian stops reported by the NYPD over five consecutive years from 2011 to 2015, and 2019 starting on January 1, 2011, to November 29, 2019, were analyzed (City of New York, 2020). The data selected are made publicly available online by the NYPD, and it contains information from the required UF-250 forms that are completed by officers for each stop. To answer research questions 1 and 2, these data were analyzed descriptively. 
Importantly, since stop-and-frisk are two separate actions, the number of reported stops does not equal the number of frisks. A civilian could be stopped but might not be frisked by an officer for any concealed weapons. The officer can only conduct the second portion of the practice if they suspect that the civilian is a threat to their safety. In addition, a civilian does not have to be under arrest to be frisked or vice versa. Often, a frisk will lead to an arrest, but that is not always the case. The action of arrest could happen without a frisk. However, the actions of frisk and arrest cannot happen without the initial stop by law enforcement.

This research chose to examine the disparities between two race categories: Black and White. Due to the likelihood of ambiguities in race classifications by the NYPD, other individuals of color were categorized as "Other". There was also an unknown classification for individuals; whose race was not initially identified by the NYPD. This research, however, only compared Black civilians to White civilians. 'Other' and 'Unknown' categories were only included to reflect the complete SQF database. These variables were utilized to answer research questions 1 and 2. Specific variables from the SQF data were drawn and statistically analyzed. Table 1 provides a full description of the variables included in the data analysis

To establish if the practice of stop-and-frisk post-Floyd et al. v. City of New York et al. is still engaging in racial profiling towards Black civilians, this study analyzed the data released during and postFloyd. Utilizing 81,809 reported pedestrian stops from the NYPD SQF database in 2014, 2015, and 2019, the number of stops and frisks, sorted by the race variable, were calculated. The average and total numbers of stops and frisks between Black and White civilians were examined.

To evaluate the relationship between the four variables, they were analyzed using the T-test. The race of the civilian is the independent variable that may or may not have an association with the three dependent variables: the actions of stop, frisk, and arrest. Stopand-frisk are two separate actions. A person could be stopped, but not frisked for concealed weapons. The initial stop and subsequent frisk are two factors to consider as it is likely to be dependent on the civilian's race. The last dependent variable, the apprehension of the civilian, is another factor to consider since it could also have an association with race. The apprehension of a civilian occurs with or without the action of frisk and vice versa. A person could be stopped but not frisked or arrested. Therefore, the total number of frisks and arrests does not have equal the number of initial stops in the SQF database.

The null hypothesis for this analysis was Ho: There is no association in the number of stops, frisks, and arrests between Black and White civilians. The alternative hypothesis for this analysis was Ha: there is an association in the number of stops, frisks, and arrests between Black and White civilians. If the p-value is greater than the alpha value $(\alpha=0.05)$ then there was not enough evidence to support the rejection of the null hypothesis. On the other hand, if the p-value was less than the alpha value $(\alpha=0.05)$, then there is sufficient evidence to support the claim that there is an association between a civilian's race and the number of stops, frisks, and arrests.

\section{Results}

Question 1: The reported stops $(\mathrm{N}=81,809)$ in 2014, 2015, and 2019, based on race and frisked variables, were examined to answer question 1 . The average number of Black civilians stopped and frisked by the NYPD was higher compared to White civilians. The separate findings indicate that NYPD is still engaging in the racial profiling of Black civilians, despite the remedial process implemented by the Southern District Court of New York and promises of reforms by Mayor de Blasio.

Utilizing 81,809 reported pedestrian stops from the SQF database in 2014, 2015, and 2019, the number of stops and frisks, sorted by the race variable, were calculated. The total number of Black civilians stopped and frisked were higher compared to their White counterparts. Table 2 includes the total number and percentage of the stops reported in the three years postFloyd. The number of reported stops were sorted according to the race and frisked variables.

In 2019, the number of Black civilians that were stopped were approximately six times higher compared to White civilians and when frisked, they were approximately eight times more likely to be searched. Overall, the total number of Black civilians 
stopped and frisked by the NYPD remains higher compared to the number of White civilians.

Upon further analysis, as shown in Figure 1 and Figure 2, Black civilians made up of more than half of the total average reported stops and frisks in the three years post-Floyd. Despite a drop in the number of stops reported by the NYPD post-Floyd, the findings have indicated that the NYPD is still engaging in racial profiling in 2019, despite the remedial process implemented by the Southern District Court of New York and Mayor de Blasio's promise.

\section{Question 2:}

A total of $1,492,295$ pedestrian stops were reported by the NYPD over five consecutive years from 2011 to 2015, and 2019 were utilized (see Table 3). The T-test (see Table 4 and Table 5) evaluated the relationship between the independent variable and the three dependent variables from 2011-2013 and 20142015 and 2019. Based on the history of policing in New York City before Floyd, it is likely that a civilian's race influences their interaction with the police. Historical events such as the Civil Rights have portrayed Black civilians as dangerous and aggressive individuals. The implicit bias against Black communities by the police made them more vulnerable to being stopped, frisked, and arrested.

From 2011 to 2015, and 2019, a total of $1,492,295$ pedestrians stops were reported by the NYPD. Of those numbers, 783,671 Black civilians were stopped compared to 142,187 White civilians (see Table 3). Based on this statistic, Black civilians were five times more likely to be stopped than White civilians by the NYPD in the past. Upon analyzing the relationship between a civilian's race and the number of reported stops before and after Floyd (see Table 4 and Table 5), there is evidence to reject the null hypothesis. The significance level or $\mathrm{p}$-value was 0.00 $(0 \%)$, less than the chosen significance level $(\alpha=0.05)$. Figure 3 also reflects the disparity in the number of stops between Black and White civilians. In sum, there is sufficient evidence to support the alternative hypothesis' claim that there is an association between a civilian's race and the number of stops.

The significance level or p-value between a civilian's race and the number of reported frisks, as shown in Table 4 and Table 5, rejects the null hypothesis. The significance level, throughout the years, was $0.00(0 \%)$. This value is less than the chosen significance level $(\alpha=0.05)$, which means that there is sufficient evidence to accept the alternative hypothesis' claim that there is an association between a civilian's race and the number of frisks. Furthermore, as shown below in Figure 4, the frisk rate of Black civilians remains significantly higher compared to White civilians post-Floyd.

Out of the 1,492,295 pedestrian stops, only 103,815 civilians were arrested by the NYPD (see Table 3). As shown in Table 4 and Table 5, the significance level or p-value of arrests was $0.00(0 \%)$, this value is less than the chosen significance level $(\alpha$ $=0.05)$; thus, this study rejects the null hypothesis. There is overall evidence to accept there is an association between a civilian's race and the number of arrests. In 2019, Black civilians were approximately five times more likely to be arrested compared to White civilians, as shown below in Figure 5. Furthermore, the vast disparity between the number of stops and arrests means that out of 1,492,295 reported stops, only $6.95 \%$ of those civilians were arrested (see Table 3 ).

\section{Discussion}

The use of stop-and-frisk as a crime control policy in New York City has created a loophole for law enforcement to racially profile and harass individuals from communities of color, specifically Black civilians (Floyd et al. v. City of New York et al., 2013; New York State Office of the Attorney General, 1999). This study compares the racial disparities in reported stops, frisks, and arrests between Black and White civilians. SQF data released by the NYPD before, during, and after Floyd et al. v. City of New York et al., including the latest 2019 data were utilized. Race, frisks, and arrests were used as variables to answer the research questions. Utilizing the SQF data, this study seeks (1) to determine if the NYPD post-Floyd et al. v. City of New York et al. is still engaging in racial profiling towards Black civilians; and (2) to evaluate the relationship between a civilian's race and the number of stops, frisks, and arrests. In sum, this section discusses the findings of questions 1 and 2.

Floyd et al. v. City of New York et al. (2013) ruled that the NYPD had adopted an unconstitutional policy of racial profiling via SQF, and it was used by the police department to discriminate against 
individuals from the communities of color. To determine if the NYPD is still engaging in racial profiling of Black civilians, this study analyzed the data released in 2014, 2015, and 2019. It found that the total and average number of Black civilians stopped and frisked were higher compared to their White counterparts. Despite a drop in the number of stops post-Floyd, the findings have indicated that the NYPD is still engaging in racial profiling in 2019 regardless of the Joint Remedial Process and Mayor Bill de Blasio's promise. These findings correlate with the existing statistics on how Black civilians are overrepresented in policies and practices, such as stopand-frisk (Farrell et al., 2004; Floyd et al. v. City of New York et al., 2013; Holmes, 2000; New York State Office of the Attorney General, 1999; Smith \& Alpert, 2007). In addition, the findings support previous studies which indicated that Black civilians are twice as likely as White civilians to be stopped for suspicion or subjected to pat-down searches (Fagan \& Davies, 2000; New York Civil Liberties Union and the NYCLU Foundation, 2013).

This study addressed the relationship between a civilian's race and the number of stops, frisks, and arrests. The null hypothesis for this analysis was that there is no association in the number of stops, frisks, and arrests between Black and White civilians. The alternative hypothesis was that there is an association between the independent and dependent variables. The T-test analyses before, during, and after-Floyd revealed that there was sufficient evidence to accept the alternative hypothesis. By establishing that a civilian's race does affect the number of stops, frisks, and arrests further support the evidence that the NYPD has continued to engage in the racial profiling of Black civilians. The findings of 1 and 2 suggest that the Joint Remedial Process and Mayor de Blasio's promise of reform did not work.

The findings support the idea that the policy of $\mathrm{SQF}$, which was introduced as a crime control policy, is a tool of legal oppression via racial profiling. As previously mentioned, the vast disparity between the number of stops and arrests seems troubling. Out of $1,492,295$ reported pedestrian stops, approximately $6.95 \%(103,815)$ of civilians were arrested. Of the $6.95 \%$ arrested, Black civilians made up more than half of the percentage while less than $0.8 \%$ of White civilians were arrested between 2011 to 2015 and 2019. This finding further indicates that $1,388,480$ of innocent civilians were subjected to baseless police suspicion and stop. Therefore, it is evident that as a crime control policy, the practice of stop-and-frisk has not been utilized correctly and constitutionally.

Through the practice stop-and-frisk, the NYPD showed deliberate indifference to their officers' misconduct. Their actions not only diminished police legitimacy, but the NYPD is also an example of police misconduct that must be addressed and reformed throughout the country.

\section{Conclusion}

In the landmark case of Floyd et al. v. City of New York, et al. (2013), the Southern District Court of New York ruled that the NYPD was engaging in unconstitutional stop-and-frisk practices and were racially profiling Black and Hispanic civilians. At its peak in 2011, SQF saw a record number of 685,724 reported pedestrian stops. By 2019, this number has decreased by approximately $98 \%$ (City of New York, 2020). The ruling of Floyd, the Joint Remedial Process, and a new mayorship resulted in a dramatic reduction of the reported SQF stops. While the reduction was noted, the racial profiling of Black civilians before, during, and after-Floyd had yet to be analyzed.

This study examined a total of 1,492,295 pedestrian stops reported over five consecutive years from 2011 to 2015, and 2019 starting on January 1, 2011, to November 29, 2019, to investigate the continuation of the practice of stop-and-frisk in New York City (City of New York, 2020). Based on the findings of question 1, the NYPD post-Floyd has continued to engage in the racial profiling of Black civilians. Regardless of the drop of recorded stops in 2014, 2015, and 2019, statistical evidence continues to show a vast difference in the racial disparities between Black and White civilians as it did from 2011 to 2013. Black civilians were statistically overrepresented as they made up more than half of the average number of stops and frisks. In sum, these findings indicate that the Joint Remedial Process and Mayor de Blasio's promise of reforms did not effectively bring changes to the NYPD.

To further support the indication of NYPD continued racial profiling of Black civilians. The T-test 
analysis in question 2 suggests that there is an association between a civilian's race and the number of stops, frisks, and arrests. In other words, a civilian's race does affect the chances of them being stopped, frisked, and arrested by law enforcement.

The results of questions 1 and 2 reinforce the idea that, despite a drop in the number of reported cases, the NYPD through SQF policy continues to engage in racial profiling of Black civilians. Black civilians continue to remain overrepresented in policing policies and practices. The result of this study contributes to the existing statistics (Farrell et al., 2004; Floyd et al. v. City of New York et al., 2013; Holmes, 2000; New York State Office of the Attorney General, 1999; Smith \& Alpert, 2007).

SQF was championed by both Mayor Giuliani and Mayor Bloomberg as a strategy to reduce crime and bring order to New York City. Both men credited the use of SQF to the reduction of crime (Badger, 2014; Cooper, 2018; Fagan \& Davies, 2000; Keating \& Stevens, 2020; Morrow et al., 2017). However, it was indicated that the long-term downward trend in crime continued to decrease even after the number of reported stops began dropping post-Floyd (Keating \& Stevens, 2020; New York Civil Liberties Union, 2019). This fact demonstrated that the SQF policy was never meant to be a crime control strategy but a tool of legal oppression against Black civilians. The significant numbers of Black civilians found by this study reinforce the idea that the practice of stop-and-frisk is a racist/biased policing practice.

In any study, the limitations must also be addressed. Data is one of the limitations of this study. Research has found that some officers failed to complete the UF-250 form for their stop-and-frisk encounters. Only $10 \%$ to $70 \%$ of the SQF stops were completely reported in the UF-250 forms (JonesBrown et al., 2013; New York Civil Liberties Union, 2019). In addition, the SQF data may not completely capture the true extent of the stop-and-frisk encounters. Even so, the reported data might be nonrandom and might not be generalizable (Levchak, 2017; Morrow et al., 2018). Another limitation involves the accuracy of race and ethnicity reported by the NYPD. This study included an 'Unknown' classification for individuals; whose race was not initially identified by the NYPD. The ambiguity of the 'Unknown' race classification could have changed the data if they had been correctly identified. Finally, this study only focused on Black civilians' experience with law enforcement. Other individuals of color might not share the same engagement with law enforcement.

There are many directions for future research to study in terms of the practice of stop-and-frisk. For example, this study was a case study of New York City and its version of stop-and-frisk. There are reasons to believe that the cases in New York City and the experiences of its civilians are comparable. As previously mentioned, in cities such as Oakland and Ferguson, Black individuals are more likely to be stopped and fined compared to their White counterparts (Hetey et al., 2016; Taylor, 2016). However, there are also variations in cities, such as Los Angeles, Philadelphia, and Chicago, on how police departments design their stop-and-frisk programs and how they share data (Stack, 2018). Cities across the U.S. have different demographics and crime rates. Thus, they will never share the same system of stopand-frisk. However, the racism inherent in the practice of stop-and-frisk, noted by the NAACP before the ruling of Terry $\mathrm{v}$. Ohio, might provide a similar problem with other cities as it did with New York City (Daniels et al. v. the City of New York et al., 2001; Floyd et al. v. City of New York et al., 2013; Kurland \& Casper, 1975).

Another direction would be to focus on the SQF policy in New York City in the years following with the recent budget cut amid the COVID-19 pandemic, economic crisis, and the latest movement to defund the police (Rubinstein \& Mays, 2020). Mayor Bill de Blasio and the City Council agreed to cut one billion dollars from the NYPD's operating budget due to the economic shutdown by the coronavirus and protests to defund the police after numerous deaths of unarmed Black civilians across the nation.

More than ever, the U.S. is facing a political turmoil that once again raises the questions of police legitimacy. Racism and bias inherent in policing policy and practices, such as stop-and-frisk, diminish police legitimacy and trust from the citizens. New York City is only one of the many examples of racial profiling. Without a complete and successful reform of police departments and its personnel, discriminatory and implicit bias practices will continue to strain police- 
community relationships and significantly tarnish police legitimacy.

\section{Acknowledgements}

Foremost, I would like to express my sincere gratitude and appreciation to my faculty advisor, Dr. Emily Troshynski, for her continuous support and motivation through my research. I would also like to thank the rest of my thesis committee: Dr. Dan Bubb and Dr. Todd Robinson, for their patience and enthusiasm. For their guidance, I would like to recognize Ms. Susie Skarl, Mr. Joshua Donnelly, and Daniel DeLuca for providing me with the tools and resources I needed.

I want to acknowledge the support and love of my family and friends, especially Judy, Sammy, Nicole, Emilie, Christine, Amber, and Rossi. Even on my worst days, they were the ones who kept me going. This thesis would not have been possible without their input and constant encouragement.

\section{References}

Alexander, M. (2010). The new Jim Crow: Mass incarceration in the age of colorblindness. The New Press.

American Civil Liberties Union. (2020). Racial profiling: Definition.

https://www.aclu.org/other/racial-profilingdefinition

Badger, E. (2014, August 14). 12 years of data from New York City suggest stop-andfrisk wasn't that effective. Washington Post. https://www.washingtonpost.com/news/wonk/ wp/2014/08/21/12-years-of-data-from-newyork-city-suggest-stop-and-frisk-wasnt-thateffective/

Belen, A. E. (2018). New York City stop \& frisk joint remedial process. The New York City Joint Remedial Process. https://www.jamsadr.com/files/uploads/docum ents/articles/belen-new-york-city-jointremedial-process-may-2018.pdf

Bobo, L. D., \& Thompson, V. (2006). Unfair by design: The war on drugs, race and the legitimacy of the criminal justice system. Social Research, 73(2), 445-472. http://nrs.harvard.edu/urn-

3:HUL.InstRepos:3196586

Brooks, O. (2020). Police brutality and Blacks: An American immune system disorder.

Journal of the National Medical Association, 112(3), 239-241. https://doi.org/10.1016/j.jnma.2020.06.003

Brown, E., \& Barganier, G. (2018). Race and crime: Geographies of injustice. University of California Press.

Center for Constitutional Rights. (2012, October 1). Daniels, et al. v. City of New York. https://ccrjustice.org/home/what-we-do/ourcases/daniels-et-al-v-city-new-york

Center for Constitutional Rights. (2019, June 11). Joint remedial process in Floyd v. City of New York: What you need to know. https://ccrjustice.org/home/get-involved/toolsresources/fact-sheets-and-faqs/timeline-floydv-city-new-york

Center for Constitutional Rights. (2020, January 16). Floyd, et al. v. City of New York, et al. https://ccrjustice.org/home/what-wedo/our-cases/floyd-et-al-v-city-new-york-et-al

City of New York. (2020). Stop, Question and Frisk Data [Data set]. New York Police Department. https://www1.nyc.gov/site/nypd/stats/reportsanalysis/stopfrisk.page

Cooper, F. R. (2018). A genealogy of programmatic stop and frisk: The discourse-to-practicecircuit. University of Miami Law Review, 73(1), 1-77.

https://scholars.law.unlv.edu/cgi/viewcontent. cgi article $=2162 \&$ context $=$ facpub

Daniels v. City of New York, 138 F. Supp. 2d 562 (2001).

de Blasio, B. (2013). Safe streets, safe neighborhoods across New York

City.https://web.archive.org/web/2013111205

2142/http://www.billdeblasio.com/issues/crim e-fighting-public-safety

Fagan, J., \& Davies, G. (2000). Street stops and broken windows: Terry, race, and disorder in New York City. Fordham Urban Law Journal, 28(2), 457-504. https://ir.lawnet.fordham.edu/ulj/vol28/iss2/2

Fagan, J., \& Geller, A. (2015). Following the script: 
Narratives of suspicion in Terry stops in street policing. The University of Chicago Law

Review, 82(1), 51- 88.

https://chicagounbound.uchicago.edu/cgi/view content.cgi article $=5860 \&$ context $=\mathrm{uclrev}$

Farrell, A., McDevitt, J., Bailey, L., Andresen, C., \& Pierce, E. (2004). Massachusetts racial and gender profiling study. Northeastern

University Institute on Race and Justice. http://www.boston.com/globe/metro/packages/ tickets/profiling_finalreport.pdf

Floyd v. City of New York, 959 F. Supp. 2d 540 (2013).

Gabrielson, R., Sagara, E., \& Jones, R. G. (2014, October 10). Deadly force, in Black and White. ProPublica. https://www.propublica.org/article/deadlyforce-in-black-and-white

Hetey, R. C., Monin, B., Maitreyi, A., \& Eberhardt, J.L. (2016). Data for change: A statistical analysis of police stops, searches, handcuffings, and arrests in Oakland, Calif., 2013-2014. SPARQ: Social Psychological Answers to Real-World Questions. https://stacks.stanford.edu/file/druid:by412gh2 838/Data\%20for\%20Change\%20(June\%2023) .pdf

Holmes, M. D. (2000). Minority threat and police brutality: Determinants of civil rights criminal complaints in U.S. municipalities.

Criminology, (38)2, 343-368.

https://doi.org/10.1111/j.1745-

9125.2000.tb00893.x

Jones-Brown, D., Stoudt, B. G., Johnston, B., \& Moran, K. (2013). Stop, question, \& frisk policing practices in New York City: A primer (revised ed.). Center on Race, Crime and Justice at John Jay College of Criminal Justice.

http://www.atlanticphilanthropies.org/wpcontent/uploads/2015/09/SQF_Primer_July_2 013.pdf

Keating, D., \& Stevens, H. (2020, February 27). Bloomberg said 'stop and frisk' decreased crime. Data suggests it wasn't a major factor in cutting felonies. Washington Post. https://www.washingtonpost.com/nation/2020/ 02/27/bloomberg-said-stop-frisk-decreasedcrime-data-suggests-it-wasnt-major-factorcutting-felonies/?arc404=true

Kramer, R., \& Remster, B. (2018). Stop, frisk, and assault? Racial disparities in police use of force during investigatory stops. Law \& Society Review, 52(4), 960-993. https://doi.org/10.1111/lasr.12366

Kurland, P., \& Casper, G. (1975). Landmark briefs and arguments of the Supreme Court of the United States (Vol. 66). University Publications of America.

Levchak, P. J. (2017). Do precinct characteristics influence stop-and-frisk in New York City? A multi-level analysis of post-stop outcomes.

Justice Quarterly, 34(3), 377-406. https://doi.org/10.1080/07418825.2016.11623 20

McDonald, P. P., \& Greenberg, S. (2002). Managing police operations: Implementing the New York crime control model Compstat. Wadsworth Publishing.

Meares, T. (2014). The law and social science of stop and frisk. Annual Review of Law and Social Science, 10(1), 335-352.

https://doi.org/10.1146/annurev-lawsocsci102612-134043

Meares, T. (2015). Programming errors:

Understanding the constitutionality of stop and frisk as a program, not an incident. The University of Chicago Law Review, 82(1), 159-79.

https://chicagounbound.uchicago.edu/cgi/view content.cgi article $=5866 \&$ context $=$ uclrev .

Morrow, W. J., Berthelot, E. R., \& Vickovic, S. G. (2018). Police use of force: An examination of the minority threat perspective. Criminal Justice Studies, 31(4), 368-387. https://doi.org/10.1080/1478601X.2018.15138 37

Morrow, W. J., White, M. D., \& Fradella, H. F. (2017). After the stop: Exploring the racial/ethnic disparities in police use of force during Terry stops. Police Quarterly, 20(4), 367-396. https://doi.org/10.1177/1098611117708791 Nash, D. A. (2018). The origins of New York's stop- 
and-frisk: Police, race, and Civil Rights activism, 1957-1968. (Publication No. 10838559) [Doctoral dissertation, Northwestern University]. ProQuest Dissertations Publishing.

New York Civil Liberties Union. (2019). Stop-andfrisk in the de Blasio era. https://www.nyclu.org/sites/default/files/field_ documents/20190314_nyclu_stopfrisk_singles .pdf

New York Civil Liberties Union and the NYCLU Foundation. (2013, May 22). Analysis finds racial disparities, ineffectiveness in NYPD stop-and-frisk program; links tactic to soaring marijuana arrest rate.

https://www.nyclu.org/en/pressreleases/analysis-finds-racial-disparitiesineffectiveness-Nypd-stop-and-frisk-programlinks

New York State Office of the Attorney General. (1999). Stop and frisk report. https://ag.ny.gov/sites/default/files/pdfs/burea us/civil_rights/stp_frsk.pdf.

Noppe, J., Verhage, A., \& Van Damme, A. (2017). Police legitimacy: An introduction. Policing: An International Journal, 40(3), 474-479. https://doi.org/10.1108/PIJPSM-05-2017-0058

Quillian, L., \& Pager, D. (2010). Estimating risk: Stereotype amplification and the perceived risk of criminal victimization. Social Psychology Q, 73(1), 79-104. https://scholar.harvard.edu/pager/publications/ estimating-risk-stereotype-amplification-andperceived-risk-criminal

Richardson, L. S. (2017). Implicit racial bias and racial anxiety: Implications for stops and frisks. Ohio State Journal of Criminal Law, 15(1), 73-88. http://hdl.handle.net/1811/85584

Rubinstein, D., \& Mays, J. C. (2020, June 30). Nearly $\$ 1$ billion is shifted from police in budget that pleases no one. The New York Times. https://www.nytimes.com/2020/06/30/nyregio n/nypd-budget.html

Schwartz, A. (1996). 'Just take away their guns': The hidden racism of Terry v. Ohio. Fordham Urban Law Journal, 23(2), 317-375. https://ir.lawnet.fordham.edu/ulj/vol23/iss2/5/
Shames, M., \& McCormack, S. (2019, March 14). Stop and frisks plummeted under New York mayor Bill de Blasio, but racial disparities haven't budged. ACLU. https://www.aclu.org/blog/criminal-lawreform/reforming-police/stop-and-frisksplummeted-under-new-york-mayor-bill-de

Smiley, C. (2019). Release in the era of BLM: The nexus of Black Lives Matter and prisoner reentry. The Prison Journal, 99(4), 396-419. https://doi.org/10.1177/0032885519852077

Smith, D. C., \& Bratton, W. J. (2001). Performance management in New York City: Compstat and the revolution of police management. In D. W. Forsythe (Ed.), Quicker, better, cheaper? Managing performance in American government. Rockefeller Institute Press.

Smith, M. R., \& Alpert, G. P. (2007). Explaining police bias: A theory of social conditioning and illusory correlation. Criminal Justice and Behavior, 34(10), 1262-1283. https://doi.org/10.1177/0093854807304484

Smith, M. R., Kaminski, R. J., Alpert, G., Fridell, L., MacDonald, J., \& Kubu, B. (2009). Multimethod evaluation of police use of force outcomes: Final report to the National Institute of Justice. National Institute of Justice. https://www.ncjrs.gov/pdffiles 1/nij/grants/231 176.pdf

Stack, T. (2018). Racial biases within stop and frisk: The product of inherently flawed judicial precedent. [Thesis, Ramapo College]. Ramapo Journal of Law and Society.

Sunshine, J., \& Tyler, T. R. (2003). The role of procedural justice and legitimacy in shaping public support for policing. Law and Society Review, 37(3), 513-548. https://doi.org/10.1111/1540-5893.3703002

Taylor, K. Y. (2016). From \#BlackLivesMatter to Black liberation. Haymarket Books.

Terry v. Ohio, 392 U.S. 1 (1968).

Thompson, A. (1999). Stopping the usual suspects: Race and the Fourth Amendment. N.Y.U. Law Review, 74(4), 956-1013. https://www.nyulawreview.org/issues/volume74-number-4/stopping-the-usual-suspectsrace-and-the-fourth-amendment/ 
Tyler, T., \& Huo, Y. (2002). Trust in the law: Encouraging Public Cooperation with the Police and Courts. Russell Sage.

United States Government Accountability Office. (2000). Racial profiling: Limited data available on motorist stops.

https://www.gao.gov/products/GGD-00-41
Ward, S. F. (2014, March 1). Has 'stop and frisk' been stopped? ABA Journal. https://www.abajournal.com/magazine/article/ has_stop_and_frisk_been_stopped 
Appendix A: Table 1. Variable names and descriptions

\begin{tabular}{ll}
\hline \multicolumn{1}{c}{ Variable Name } & \multicolumn{1}{c}{ Description } \\
$\begin{array}{ll}\text { Independent Variable } \\
\text { Race }\end{array}$ & $\begin{array}{l}\text { Categories created from Black, White, Other, and } \\
\text { Unknown. }\end{array}$ \\
$\begin{array}{ll}\text { Dependent Variables } \\
\text { Number of stopped }\end{array}$ & $\begin{array}{l}\text { Indicated by the total numbers of pedestrians recorded each } \\
\text { year }\end{array}$ \\
Number of frisked & Was suspect frisked? Yes or No \\
Number of arrest & Was suspect arrested? Yes or No
\end{tabular}

Note. The category, Other, is comprised of individuals from the communities of color: Asian, Pacific Islander, Native American, and Hispanic. 
Appendix B: Table 2. Reported stop and frisks in 2014, 2015, and 2019

Frisked

\begin{tabular}{ll|r|r|r|r|r|r|}
\hline & \multicolumn{2}{c}{ Yes } & \multicolumn{2}{c}{ No } & \multicolumn{2}{c}{ Total Stops } \\
\hline \multirow{2}{*}{ Race } & Black & 17002 & $69.9 \%$ & 7317 & $30.1 \%$ & 24319 & $100.0 \%$ \\
\cline { 2 - 9 } & White & 3064 & $56.0 \%$ & 2403 & $44.0 \%$ & 5467 & $100.0 \%$ \\
\cline { 2 - 9 } & Other & 10085 & $64.2 \%$ & 5616 & $35.8 \%$ & 15701 & $100.0 \%$ \\
\cline { 2 - 9 } & Unknown & 194 & $64.7 \%$ & 106 & $35.3 \%$ & 300 & $100.0 \%$ \\
\hline
\end{tabular}

Frisked

\begin{tabular}{|c|c|c|c|c|c|c|c|}
\hline \multicolumn{2}{|l|}{2015} & \multicolumn{2}{|c|}{ Yes } & \multicolumn{2}{|c|}{ No } & \multicolumn{2}{|c|}{ Total Stops } \\
\hline Race & Black & 8513 & $71.2 \%$ & 3437 & $28.8 \%$ & 11950 & $100.0 \%$ \\
\hline & White & 1387 & $55.2 \%$ & 1127 & $44.8 \%$ & 2514 & $100.0 \%$ \\
\hline & Other & 5273 & $66.1 \%$ & 2704 & $33.9 \%$ & 7977 & $100.0 \%$ \\
\hline & Unknown & 84 & $68.9 \%$ & 38 & $31.1 \%$ & 122 & $100.0 \%$ \\
\hline & Total & 15257 & & 7306 & & 22563 & \\
\hline
\end{tabular}

Frisked

\begin{tabular}{|c|c|c|c|c|c|c|c|}
\hline \multicolumn{2}{|l|}{2019} & \multicolumn{2}{|c|}{ Yes } & \multicolumn{2}{|c|}{ No } & \multicolumn{2}{|c|}{ Total Stops } \\
\hline Race & Black & 4626 & $58.0 \%$ & 3355 & $42.0 \%$ & 7981 & $100.0 \%$ \\
\hline & White & 528 & $43.5 \%$ & 687 & $56.5 \%$ & 1215 & $100.0 \%$ \\
\hline & Other & 2418 & $57.9 \%$ & 1760 & $42.1 \%$ & 4178 & $100.0 \%$ \\
\hline & Unknown & 52 & $61.2 \%$ & 33 & $38.8 \%$ & 85 & $100.0 \%$ \\
\hline & Total & 7624 & & 5835 & & 13459 & \\
\hline
\end{tabular}


Appendix C: Table 3. Total number of stops, frisks, and arrests from 2011-2015 and 2019

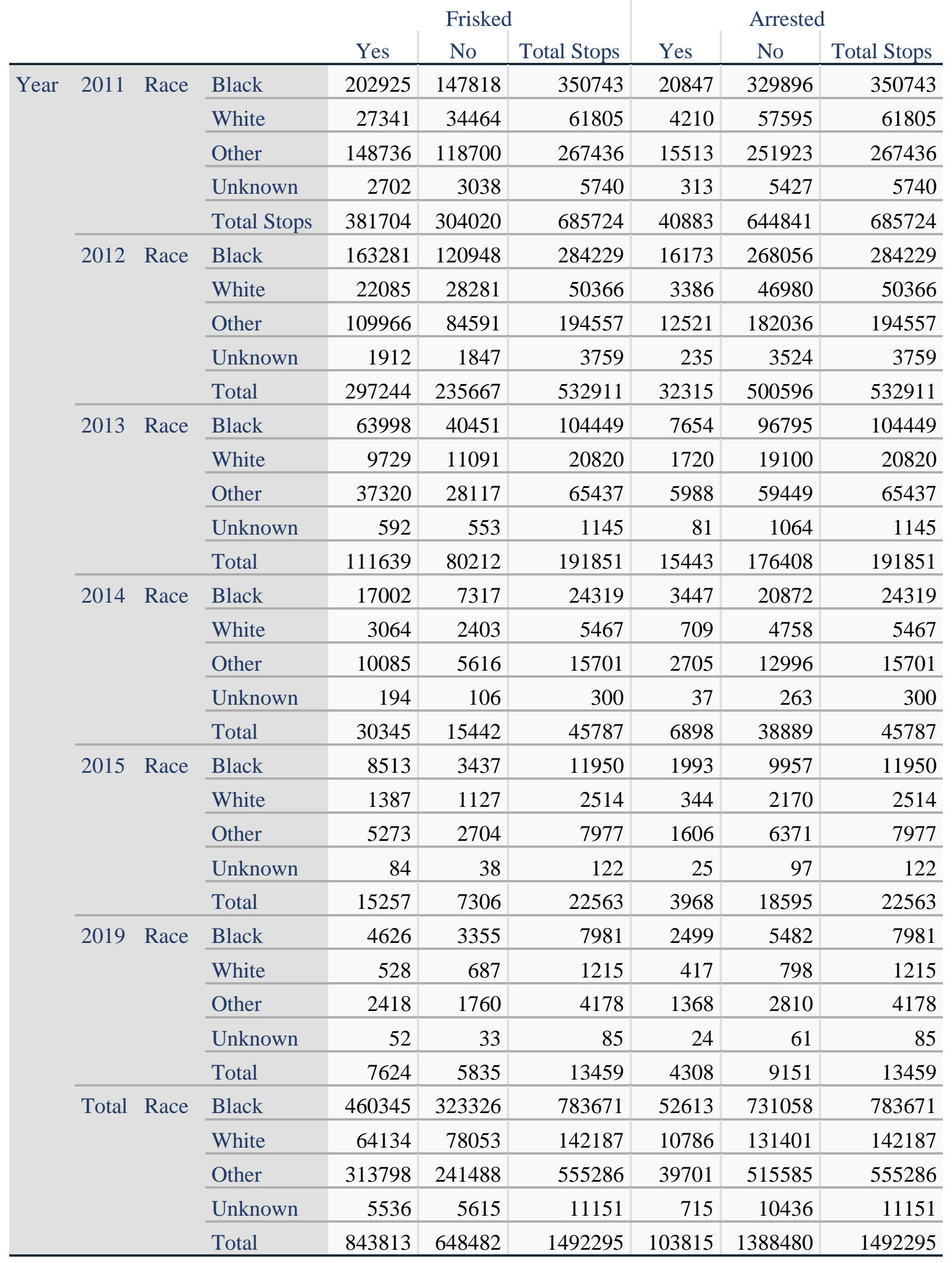


Appendix D: Table 4. T-test from 2011-2013 for stops, frisks, and arrests

\begin{tabular}{|c|c|c|c|}
\hline $2011-2013$ & Race & $\mathrm{N}$ & Std. Error Mean \\
\hline \multirow[t]{2}{*}{ Stops } & Black & 739421 & .001 \\
\hline & White & 132991 & .002 \\
\hline \multirow[t]{2}{*}{ Frisks } & Black & 739421 & .001 \\
\hline & White & 132991 & .001 \\
\hline \multirow[t]{2}{*}{ Arrests } & Black & 739421 & .000 \\
\hline & White & 132991 & .001 \\
\hline
\end{tabular}

\begin{tabular}{|c|c|c|c|c|c|c|c|c|}
\hline \multicolumn{9}{|c|}{$\begin{array}{c}\text { Levene's Test for } \\
\text { Equality of } \\
\text { Variances }\end{array}$} \\
\hline & & \multirow[b]{2}{*}{$\mathrm{F}$} & \multirow[b]{2}{*}{ Sig. } & \multirow{2}{*}{$\begin{array}{l}\text { Sig. }(2- \\
\text { tailed) }\end{array}$} & \multirow{2}{*}{$\begin{array}{c}\text { Mean } \\
\text { Difference }\end{array}$} & \multirow{2}{*}{$\begin{array}{l}\text { Std. Error } \\
\text { Difference }\end{array}$} & \multicolumn{2}{|c|}{$\begin{array}{l}95 \% \text { Confidence } \\
\text { Interval of the } \\
\text { Difference }\end{array}$} \\
\hline & & & & & & & Lower & Upper \\
\hline \multirow[t]{2}{*}{ Stops } & $\begin{array}{l}\text { Equal variances } \\
\text { assumed }\end{array}$ & 113.772 & .000 & .000 & -.025 & .002 & -.029 & -.021 \\
\hline & $\begin{array}{l}\text { Equal variances } \\
\text { not assumed }\end{array}$ & & & .000 & -.025 & .002 & -.029 & -.021 \\
\hline \multirow[t]{2}{*}{ Frisks } & $\begin{array}{l}\text { Equal variances } \\
\text { assumed }\end{array}$ & 1002.671 & .000 & .000 & -.137 & .001 & -.140 & -.134 \\
\hline & $\begin{array}{l}\text { Equal variances } \\
\text { not assumed }\end{array}$ & & & .000 & -.137 & .001 & -.140 & -.134 \\
\hline \multirow[t]{2}{*}{ Arrests } & $\begin{array}{l}\text { Equal variances } \\
\text { assumed }\end{array}$ & 710.261 & .000 & .000 & .010 & .001 & .008 & .011 \\
\hline & $\begin{array}{l}\text { Equal variances } \\
\text { not assumed }\end{array}$ & & & .000 & .010 & .001 & .008 & .011 \\
\hline
\end{tabular}


Appendix E: Table 5. T-test from 2014-2015 and 2019 for stops, frisks, and arrests

\begin{tabular}{|c|c|c|c|}
\hline 2014-2019 & Race & $\mathrm{N}$ & Std. Error Mean \\
\hline \multirow[t]{2}{*}{ Stops } & Black & 44250 & .004 \\
\hline & White & 9196 & .007 \\
\hline \multirow[t]{2}{*}{ Frisks } & Black & 44250 & .002 \\
\hline & White & 9196 & .005 \\
\hline \multirow[t]{2}{*}{ Arrests } & Black & 44250 & .002 \\
\hline & White & 9196 & .004 \\
\hline
\end{tabular}

\begin{tabular}{|c|c|c|c|c|c|c|c|c|}
\hline & & $\begin{array}{r}\text { Levene's } \\
\text { Equali } \\
\text { Varia }\end{array}$ & $\begin{array}{l}\text { st for } \\
\text { of } \\
\text { es }\end{array}$ & & & & & \\
\hline & & & & Sig. (2- & Mean & Std. Error & $\begin{array}{r}95 \% \text { Cor } \\
\text { Interval } \\
\text { Differ }\end{array}$ & $\begin{array}{l}\text { idence } \\
\text { f the } \\
\text { nce }\end{array}$ \\
\hline & & $\mathrm{F}$ & Sig. & tailed) & Difference & Difference & Lower & Upper \\
\hline Stops & $\begin{array}{l}\text { Equal variances } \\
\text { assumed }\end{array}$ & 199.974 & .000 & .000 & .093 & .009 & .076 & .110 \\
\hline & $\begin{array}{l}\text { Equal variances } \\
\text { not assumed }\end{array}$ & & & .000 & .093 & .008 & .077 & .109 \\
\hline Frisks & $\begin{array}{l}\text { Equal variances } \\
\text { assumed }\end{array}$ & 1232.581 & .000 & .000 & -.140 & .005 & -.150 & -.129 \\
\hline & $\begin{array}{l}\text { Equal variances } \\
\text { not assumed }\end{array}$ & & & .000 & -.140 & .006 & -.151 & -.129 \\
\hline Arrests & $\begin{array}{l}\text { Equal variances } \\
\text { assumed }\end{array}$ & 83.658 & .000 & .000 & -.020 & .004 & -.028 & -.011 \\
\hline & $\begin{array}{l}\text { Equal variances } \\
\text { not assumed }\end{array}$ & & & .000 & -.020 & .004 & -.028 & -.011 \\
\hline
\end{tabular}


Appendix F: Figure 1. Average number of reported stops in 2014, 2015, and 2019

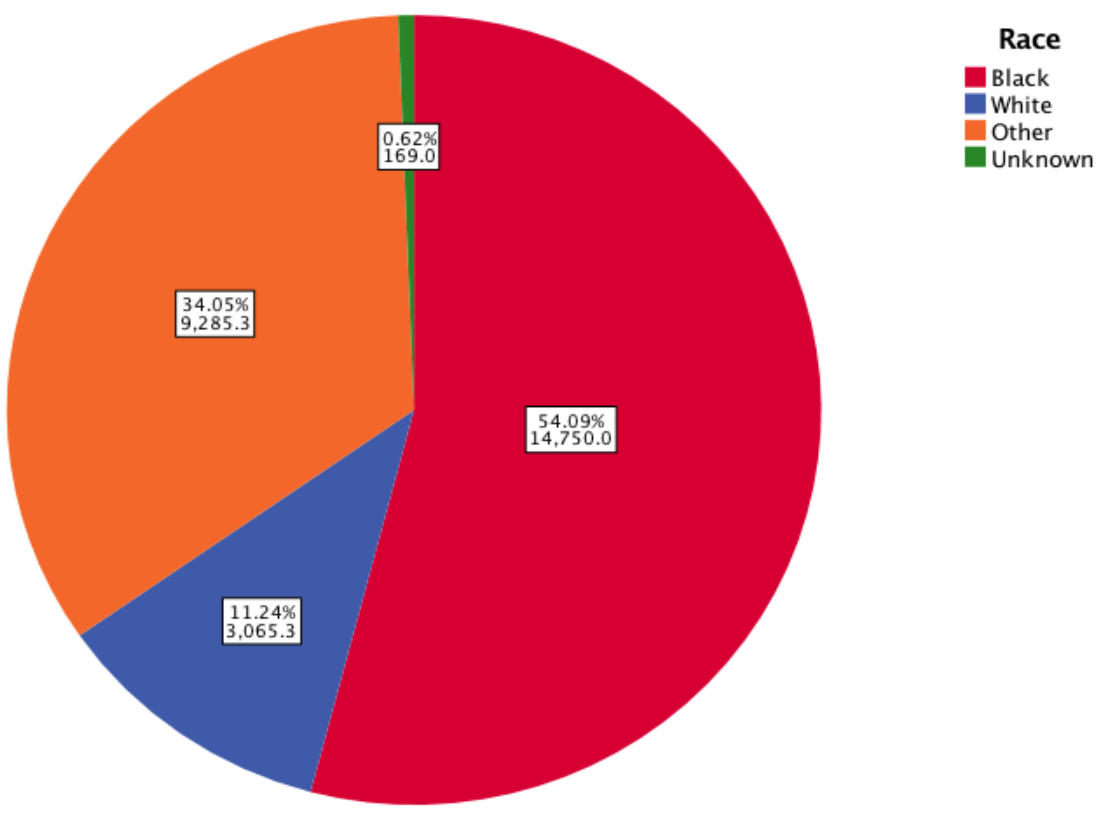

Spectra Undergraduate Research Journal - 2021 - Volume 1, Issue 2 
Appendix G: Figure 2. Average number of reported frisks in 2014, 2015, and 2019

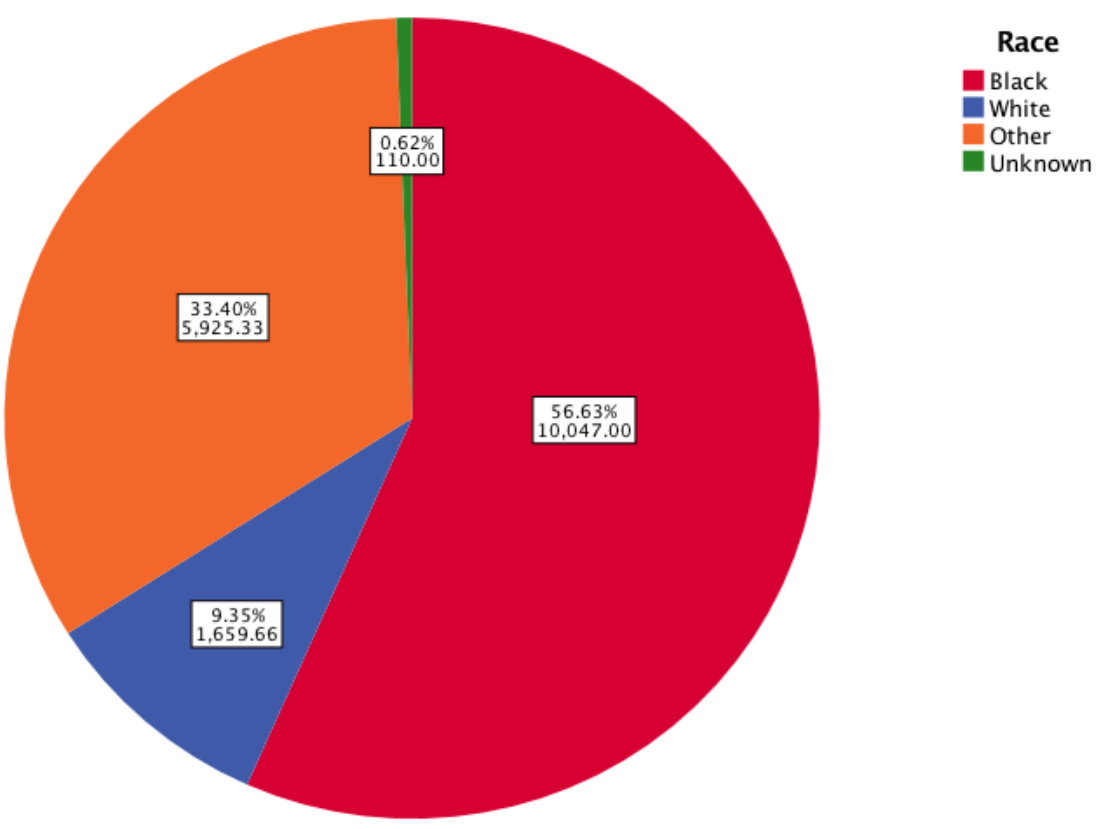

Spectra Undergraduate Research Journal - 2021 - Volume 1, Issue 2 
Appendix H: Figure 3. Number of reported stops in 2011-2015 and 2019

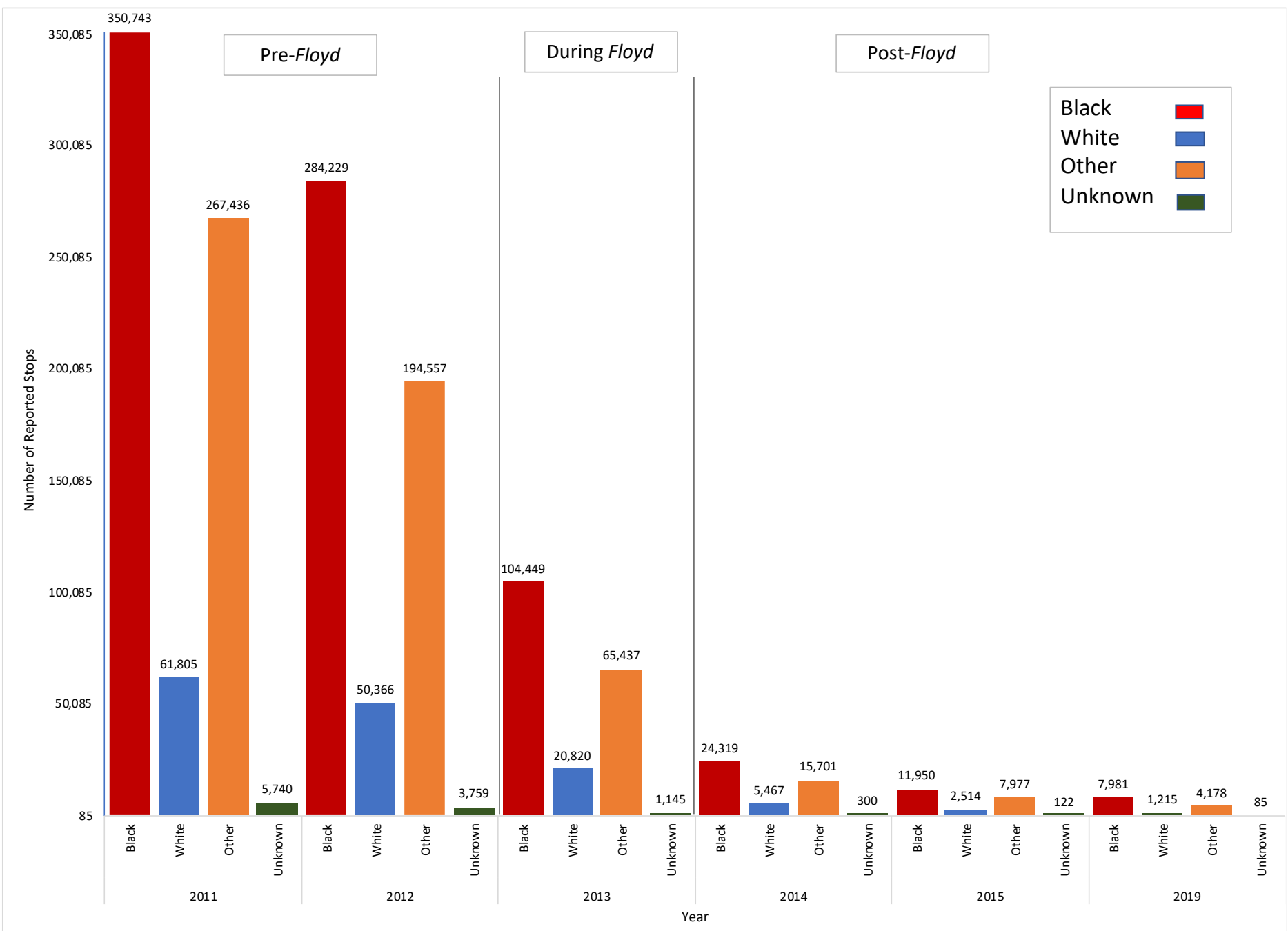


Appendix I: Figure 4. Number of reported frisks in 2011-2015 and 2019

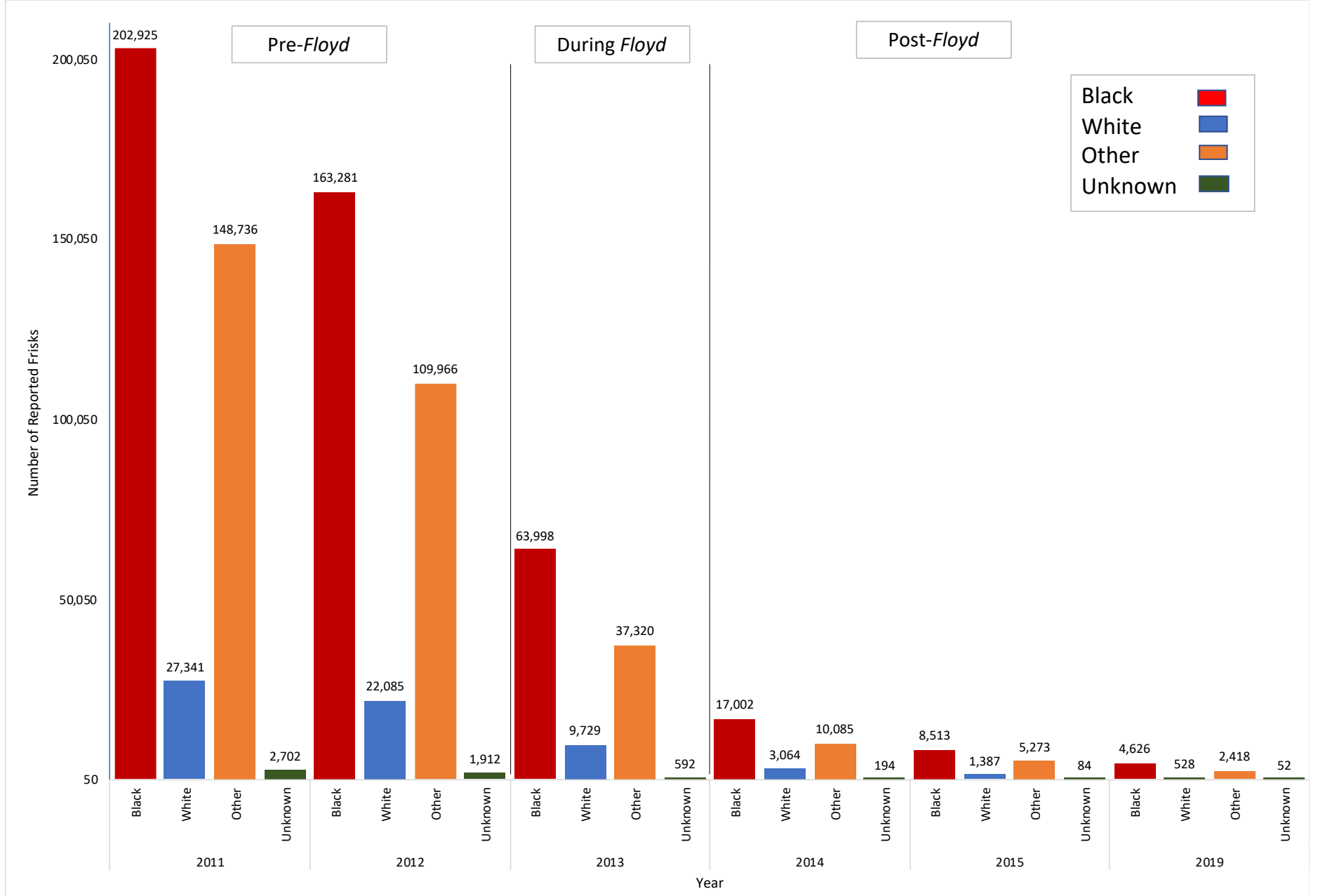


Appendix J: Figure 5. Number of reported arrests in 2011-2015 and 2019

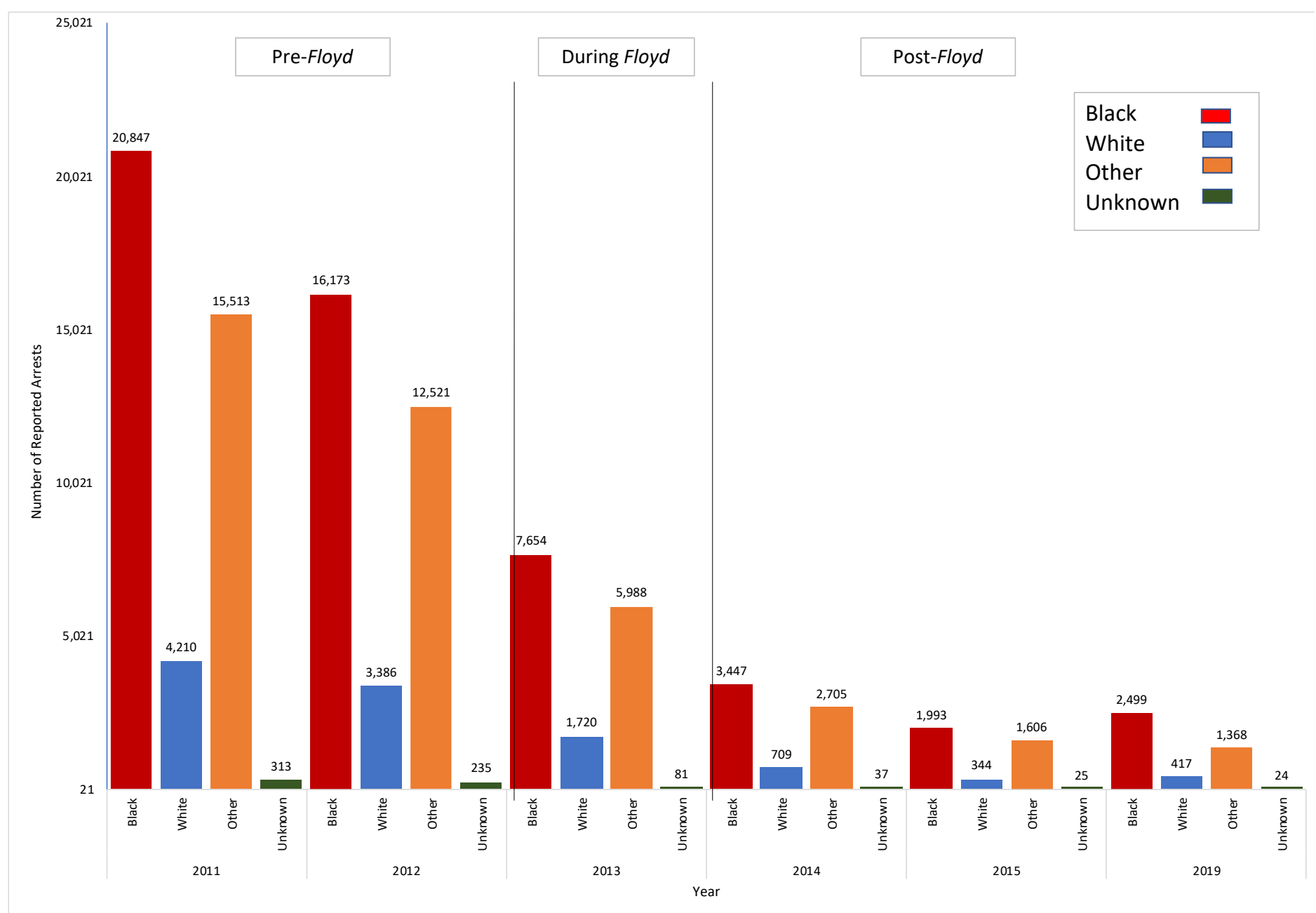

